\title{
Communication between professionals from physical rehabilitation unit and deaf clients
}

\author{
Comunicação de profissionais de unidade de reabilitação física com clientes surdos \\ Comunicación de profesionales de unidad de rehabilitación física con clientes sordos
}

Wiliam César Alves Machadoํㅡㄹ Juarez de Sousa Pereira ${ }^{1}$, Athaynne Ramos de Aguiar Prado ${ }^{1}$, Rafael André da Silva ${ }^{1}$, Vera Maria da Silva ${ }^{1}$, Nébia Maria Almeida de Figueiredo ${ }^{1}$

Objective: to identify how professionals from the local public physical rehabilitation unit communicate with deaf people seeking specialized care. Methods: exploratory descriptive study with qualitative approach conducted with 32 professionals working in physical rehabilitation through self-reporting instrument. Results: two thematic categories emerged from data analysis: Using the Brazilian Sign Language, and Improvising communication strategies to interact with deaf patients. When professionals improvise strategies to communicate with the deaf, it might create barriers that negatively affect the quality of services provided to this population. Conclusion: communication is inefficient, and effective initiatives focused on the qualification of professionals working in rehabilitation can contribute for them to master the Brazilian Sign Language, ensuring adequate care to deaf clients/patients, in the same way as those provided to people without hearing impairment. Descriptors: Deafness; Rehabilitation Services; Sign Language; Communication Barriers.

Objetivo: identificar como profissionais de unidade pública municipal de reabilitação física se comunicam com pessoas surdas que buscam atendimento especializado. Métodos: estudo exploratório, descritivo, de abordagem qualitativa, realizado com 32 profissionais que atuam em reabilitação física, através de instrumento autoaplicável. Resultados: da análise dos dados, emergiram duas categorias temáticas: Usando a Língua de Sinais Brasileira; e Improvisando estratégias de comunicação para interagir com clientes surdos. A improvisação de estratégias utilizadas pelos profissionais para se comunicar com surdos podem ocasionar barreiras que repercutem negativamente na qualidade dos serviços prestados a essa clientela. Conclusão: a comunicação é deficitária, e iniciativas efetivas focadas na habilitação dos profissionais que atuam na esfera da reabilitação, podem contribuir para que eles possam dominar a Língua de Sinais Brasileira, assegurando aos clientes surdos atendimentos adequados, como os prestados às pessoas sem deficiência auditiva.

Descritores: Surdez; Serviços de Reabilitação; Linguagem de Sinais; Barreiras de Comunicação.

Objetivo: identificar cómo profesionales de la unidad municipal de rehabilitación física se comunican con personas sordas que buscan atención especializada. Métodos: estudio exploratorio, descriptivo, de enfoque cualitativo, realizado con 32 profesionales que trabajan en rehabilitación física a través de instrumento auto aplicable. Resultados: del análisis de datos, surgieron dos categorías temáticas: Usando el Lenguaje Brasileño de Signos; Improvisación de Estrategias de comunicación para interactuar con clientes sordos. Improvisación de estrategias utilizadas por los profesionales para comunicarse con personas sordas pueden causar barreras que inciden negativamente en la calidad de los servicios prestados a esta población. Conclusión: la comunicación es deficiente, e iniciativas eficaces centradas en la cualificación de los profesionales que trabajan en el ámbito de la rehabilitación, pueden contribuir para que puedan dominar el Lenguaje Brasileño de Signos, garantizándose a los clientes sordos la atención adecuada, conforme a lo dispuestos para personas sin discapacidad auditiva. Descriptores: Sordera; Servicios de Rehabilitación; Lenguaje de Signos; Barreras de Comunicación.

\footnotetext{
${ }^{1}$ Universidade Federal do Estado do Rio de Janeiro. Rio de Janeiro, RJ, Brazil. 


\section{Introduction}

Data from the 2010 Census of the Brazilian Institute of Geography and Statistics indicate 24.5 million people with disabilities in Brazil, of which 9.7 million have some degree of hearing loss ${ }^{(1)}$. Thus, there is need to ensure an appropriate and specific assistance in health and rehabilitation services to that public, considering effective communication among their needs.

With regard to the access of disabled persons to health services, especially the deaf, there are difficulties in patient-professional interaction ${ }^{(2)}$. Listeners use oral and written language with their verbal codes for communication, a mechanism that cannot always be used by deaf people, since the absence of auditory stimulation affects the speech development. To these people, the Sign Language is recommended ${ }^{(3)}$.

It is imperative to identify the peculiarities in communicating with the deaf, seeking to respect the guiding ethical and legal principles in the various scenarios aimed at assisting the public, including health and rehabilitation services ${ }^{(4)}$.

In the health care context, the care for deaf people is ensured by law, equivalent to Constitutional Amendments, under the UN Convention on the Rights of Persons with Disabilities ${ }^{(5)}$. Nevertheless, they still face communication barriers with the professional staff of health and rehabilitation units, resulting from lack of knowledge and understanding of the Brazilian Sign Language.

There are several measures adopted in Federal, State, and Local instances, guaranteed by the Brazilian Constitution, attempting to ensure the inclusion of deaf people in the family, collective, and institutional context. In this perspective, it is essential to health professionals working in the public and private sectors to seek new paradigms that support the promotion of quality and humanized health care to deaf patients ${ }^{(6)}$.

Communication is an essential instrument for quality of life, as it leads to individual's socialization and autonomy, particularly in health care situations. When used properly, this instrument promotes humanized and inclusive assistance, constituting a quality indicator of the service provided by health professionals $^{(6-8)}$.

Through the communication process, people share messages, ideas, feelings, and emotions. This process includes verbal communication, associated with words through written or spoken language, and non-verbal communication, encompassing all information obtained by gestures, postures, facial expressions, among other abilities and body movements. In this context, the Brazilian Sign Language should represent an important tool for effective communication with the deaf ${ }^{(9-10)}$.

Brazilian Sign Language is recognized by linguistics ${ }^{(8)}$, which gives it the concept of natural language, with its own grammatical structure independent of the Portuguese language, being neurologically articulated in the same brain areas. It has spatial-visual modality, since the eyes receive shared signs produced by the hands in space. As for communicating with gestures, whether or not involving deaf people, it represents a sign language ${ }^{(11)}$.

Therefore, it is fundamental that health professionals know the sign language, because when dealing with deaf people in the workplace they must perform with appropriate skills and attitudes to provide proper services to the needs presented by these users. For this reason, the professionals' interest and commitment along with the political will of managers can contribute to change the current situation $^{(10,12)}$.

People with hearing impairment, like any other, require health and rehabilitation care, not necessarily associated with deafness itself. In general, professionals use improvised resources with signs and gestures, which they believe appropriate to transmit to the deaf what they want to express. Nonetheless, it is important to clarify that these gestural improvisations often are ineffective for communicating with the hearing-impaired ${ }^{(10)}$. 
Understanding the importance of full communication between rehabilitation teams and everyone who seeks care in public programs offered to the population, in order to ensure equality and citizenship rights to the deaf, this study aimed to identify how professionals from the local physical rehabilitation unit communicate with deaf people seeking specialized care.

\section{Method}

Descriptive study with qualitative approach conducted in the first half of 2013 with 32 professionals working in a local public unit of physical rehabilitation located in the City of Três Rios, in the South Central Region of the State of Rio de Janeiro, Brazil.

As participants inclusion criteria, we used: aged over 18 years; work in the rehabilitation unit as local public servant; provide care and/or information to its users.

It was an intentional sample comprising representatives of the sectors of physical rehabilitation service, considering that everyone should be able to communicate with deaf patients/clients.

Data collection occurred through self-reporting instrument, consisting of closed questions aimed at identifying the socio-demographic profile of the participants and the following open question: How do you communicate with the deaf?

The interviews took place at the Rehabilitation Unit, an appropriate environment for the answers to approach as close as possible everyday interaction processes with deaf clients, the unit users.

Two criteria were used for terminating the fieldwork. The first, seeking theoretical saturation in the interviews of the study participants; and the second, considering the number of participants defined by the sample, as well as seeking representativeness among the 46 professionals working in various sectors of the physical rehabilitation unit in study, since all interact with the deaf clientele.

Data originated from the interviews were analyzed in three stages according to the thematic analysis ${ }^{(13)}$. The first stage was the initial reading of the transcription of interviews recorded in digital media, the material that constituted the research corpus. In the second stage, we conducted the material exploration by identifying the thematic units. In the third stage, data were categorized according to the forms of communication used by professionals with deaf patients: Using the Brazilian Sign Language; and Improvising communication strategies to interact with deaf clients.

In order to preserve the anonymity of the study participants, we chose to identify them as Participant (P) followed by the sequence number (P1, P2-P32).

This research followed the guidelines of Resolution No. 466/2012 and was approved by the Research Ethics Committee of the Universidade Federal do Estado do Rio de Janeiro, under protocol No. 289.701.

\section{Results}

Most participants were female (72.72\%) aged between 31 and 40 years (54.54\%), thus demonstrating the predominance of females in health and rehabilitation institutions or services.

The professional categories of the study participants were: Administrator, Social Worker, Technical Coordinator, Dentist, Nurse, Physical Therapist, Speech Therapist, Porter, Nutritionist, Physical Education Professional, Educator, Psychologist, Nursing Technician, and Occupational Therapist. Only medical professionals did not have interest in participating in the study.

From the professional categories of the subjects, the majority comprised health professionals (78.1\%). Most participants had 1-5 years (33.3\%) and 6-10 years (33.3\%) of professional performance. As for the educational institution, most of them went to private institutions (78.8\%) and only 2 respondents did not attend undergraduate programs.

After several readings of the discourse contents 
brought by participants in this study, two thematic categories emerged from the analysis procedure: 1) Using the Brazilian Sign Language and 2) Improvising communication strategies to interact with deaf clients/patients.

\section{Category 1 - Using the Brazilian Sign Language}

In this category, only 4 participants (12.5\%) claimed to dominate and use the Brazilian Sign Language to communicate with deaf clients, with special reference to the following reports: I use the sign language (P17, P18, P25). I communicate with them through sign language, the language of the deaf (P19).

Other participants reported resorting to teammates who master the Brazilian Sign Language: $I$ ask for help from a teammate who master the sign language (P27). I ask for help from someone who knows it (P15).

\section{Category 2 - Improvising communication strategies to interact with deaf clients}

This category highlights several ways to improvise communication strategies used by professionals working in the physical rehabilitation unit when dealing with deaf clients in search of assistance. Since they do not master the communication through the Brazilian Sign Language they turn to writing, without realizing that the deaf literate in the Portuguese language have a objectified scheme of understanding writing, compact, without verb conjugation and prepositions employment, thus different from the conventionally used by listeners. I write it on paper so that the person can understand it in the best possible way (P2). When I cannot understand them, I ask them to write it down (P3).

Similarly, the participants resort to gestural improvisation, which often does not help for the deaf. As they do not master the communication with signals, they use unsuitable articulatory gestural codes often incomprehensible for the deaf. I try to communicate through gestures (P1). I talk to them through gestures (P4, P12).
The same applies to attempts of communicating with the deaf through mime, lip-reading, and/or speaking slowly, as reported by the study participants: Through mime (P5, P26). I use lip reading (P8, P9, P17, P23). I usually try to speak in front of the person, speaking slowly and well articulating words (P7). I do it in a way to favor lip reading (P14, $\mathrm{P} 15)$. Speaking slowly, since many times we can see/hear each other through a single glance (P28).

\section{Discussion}

As identified in the reports of the study participants, many communication barriers keep hindering the interaction between deaf people and health professionals, which makes it imperative the knowledge of these professionals regarding the Brazilian Sign Language to ensure effectiveness of health assistance and comprehensive care of the $\operatorname{deaf}^{(6)}$.

Fragments of speeches by some participants of this study reveal the implementation of improvised strategies to communicate with deaf people seeking care at the rehabilitation unit, similar to what was found in other studies carried out in health services on the same theme ${ }^{(6,14)}$.

It worth highlighting that the right to communicate in their native language, the Brazilian Sign Language, is legally guaranteed in Brazil. Failure to comply with this linguistic peculiarity hinders the access of deaf population to the services offered by the Unified Health System ${ }^{(15)}$.

Additionally, in sign language, word is called signal, which is formed from the combination of hand movement with a certain format in a particular location of the body (an area or a space in front of the body). These hand combinations, comparable to phonemes and sometimes morphemes, are referred to as parameters ${ }^{(9)}$. This represents a complex sort of gestural movements that embody the Brazilian Sign Language and is not appropriate to use improvisations considered similar and sufficient for the deaf to understand what professionals wish do communicate 
them.

We must also realize that, because they do not hear, the deaf learn and consolidate their knowledge as social groups that communicate through the visualgestural channel, mastering the sign language with little difficulty, thus enabling the development of cognitive, socio-emotional, and linguistic aspects ${ }^{(16-17)}$.

In order that professionals working in health and rehabilitation services understand that communication is an essential right of people, including deaf, it is important to take into account and focus on those rights by the inclusive perspective, considering deafness a difference that implies, among other things, respect sign language as the preferred for access to knowledge, constituting an identifying element of the deaf.

It is noteworthy that some participants seek help from teammates that dominate the Brazilian Sign Language to serve as interpret between them and the deaf. This demonstrates concern to provide satisfactory care for this clientele, realizing that no help might often compromise a long-term rehabilitation program.

Communication barriers present in meetings between deaf people and health professionals in health and/or rehabilitation units corroborate obstacles in identifying the care and assistance needs of these clients, preventing to establish appropriate treatment-planning bases for the rehabilitation program $^{(14)}$. Likewise, the deaf feels frustrated for not finding professionals able to communicate with them, to clarify their doubts, thus they are reluctant to resort to health and/or rehabilitation services.

Study conducted in the State of Paraíba, Brazil, with 36 deaf revealed that $25 \%$ did not seek health services. Of these, $44.4 \%$ justified doing so for not having a companion. Furthermore, $100 \%$ of participants reported having difficulty communicating with health professionals, often asking for the family support. Given the barriers to access, they rarely seek these services for health prevention and promotion, revealing the prevalence of curative care ${ }^{(18)}$.
Although law recognizes the Brazilian Sign Language as a form of communication and expression between deaf people and from the other towards them, there are still many difficulties to its dissemination in different areas of expertise to ensure adequate care for deaf people ${ }^{(7)}$.

Deaf people's right to health is ensured by decree, stating that from 2006 the Unified Health System services, as well as from companies that own concessions or permits of public health care services, should be carried out by professionals trained in the use of the Brazilian Sign Language or have a professional for their translation and interpretation ${ }^{(19)}$.

Nonetheless, despite this achievement in the legal plan for the health of deaf people, it is known that most Brazilian public policies addressing the deaf are still focused on oralism, an attempt to put these people in the hearing society, such as in the use of hearing aids. Study reveals the rejection of this population to such devices ${ }^{(11)}$. This difficulty of hearing society to accept deaf culture might affect the mental and emotional health of the deaf, besides hindering their access to health.

On the other hand, the disclosure to meet the legal requirements in the field of Sign Language has advanced in various areas of knowledge, as a public policy to solve the barriers present in the social inclusion of the deaf. In this sense, the profession of translator and interpreter of Brazilian Sign Language was regulated. This professional should be listener, since he has the primary function of conveying oral information to the deaf in the most reliable way ${ }^{(16)}$.

Despite the advances of public policies to improve the access to health services, there is a gap between assistance and the regulation of the Unified Health System. In this perspective, the awareness and commitment of leaders, managers and professionals in compliance with legislation is required in order to ensure the creation of favorable spaces to universal health care $^{(20)}$.

Even though deafness constitutes an invisible disability, participatory progression of the deaf in 
society is growing. Nevertheless, there are still taboos in assisting these clients due to non-inclusive skills of professionals. Therefore, there is need to invest in professional training to meet such needs, whether in theory or practice.

The full communication with deaf clients in health care facilities, including physical rehabilitation services, should focus on meeting their expectations, especially when the professionals who work in these units are able to communicate through the Brazilian Sign Language. Effective communication fosters the implementation of mutual understanding and facilitates intersectoral therapeutic measures in rehabilitation attempting to fully meet the care needs of deaf clients.

\section{Conclusion}

This study contributed to understand that professionals working in health care services, specifically in physical rehabilitation, must be prepared to interact with deaf patients/clients satisfactorily and that communication barriers have a negative effect on the quality of services provided by these professionals to the deaf clientele. Effective communication is important to achieve the goals of rehabilitation programs.

Strategies improvisation by professionals in this study to communicate with the deaf might be an alternative for communication, however it can increase the barriers between them, since it carries mistaken judgments of professionals over conventional forms of oral communication, disregarding that the logic and dynamics of communication with deaf follows a distinct rhythm of that used by listeners.

Given the difficulties reported by study participants to communicate with the deaf clientele, it is indispensable to highlight the importance of investing in the qualification of professionals working in rehabilitation of people with disabilities. With this purpose, offering Brazilian Sign Language courses is fundamental to consolidate a more inclusive society, where members of the deaf community receive adequate care, in the same way as people without hearing impairment.

\section{Collaborations}

Machado WCA, Pereira JS and Prado ARA contributed to the study design, analysis, data interpretation, drafting of the article, and final approval of the version to be published. Silva RA, Silva VM and Figueiredo NMA contributed to the study design, drafting of the article, and final approval of the version to be published.

\section{References}

1. Instituto Brasileiro de Geografia e Estatística. Censo demográfico: resultados preliminares da amostra [Internet] 2010 [citado 2015 jan 5]. Disponível em: http://www.ibge.gov.br/home/ estatistica/populacao/censo2010/resultados_ preliminaresamostra/default_resultados preliminares_amostra.shtm

2. França ISX, Pagliuca LMF, Baptista RS, França EG, Coura AS, Souza JÁ. Violência simbólica no acesso das pessoas com deficiência às unidades básicas de saúde. Rev Bras Enferm. 2010; 63(6):964-70.

3. Duarte SBR, Chaveiro N, Freitas AR, Barbosa MA, Porto CC, Fleck MP. Aspectos históricos e socioculturais da população surda. Hist Ciênc Saúde-Manguinhos. 2013; 20(4):1713-34.

4. Castro SS, Lefèvre F, Lefèvre AMC, Cesar CLG. Acessibilidade aos serviços de saúde por pessoas com deficiência. Rev Saúde Pública. 2011; 45(1):99-105.

5. Amaral FLS, Holanda CMA, Quirino MAB, Nascimento JPS, Neves RF, Ribeiro KSQS et al. Acessibilidade de pessoas com deficiência ou restrição permanente de mobilidade ao SUS. Ciênc Saúde Coletiva. 2012; 17(7):1833-40.

6. Bittencourt ZZLC, Hoehne EL. Qualidade de vida de familiares de pessoas surdas atendidas em um centro de reabilitação. Ciênc Saúde Coletiva. 2009; 14(4):1235-9. 
7. Machado WCA, Figueiredo NMA, Tonini T, Silva CRL, Silva RCL. The search for a Brazilian sign language course: a descriptive exploratory study. Online Braz J Nurs. [Internet] 2012 [cited 2015 Jan 5]; 11(2):331-45. Available from: http://www. objnursing.uff.br/index.php/nursing/article/ view/3664

8. Miranda RS, Schubert CO, Machado WCA. Communication with people with hearing disabilities: an integrative review. Rev Pesqui Cuid Fundam Online. [Internet] 2014 [cited 2015 Jan 5]; 6(4):1695-706. Available from: http://www. seer.unirio.br/index.php/cuidadofundamental/ article/view/3204/pdf_1222.

9. Magrini AM, Momensohn TMS. Comunicação entre funcionários de uma unidade de saúde e pacientes surdos: um problema? Distúrb Comun. [Internet] 2014 [citado 2015 jan 5]; 26(3):550-8. Disponível em: http://revistas.pucsp.br/index. php/dic/article/view/14880/15215

10. Machado WCA, Machado DA, Figueiredo NMA, Tonini T, Miranda RS, Oliveira GMB. Sign language: how the nursing staff interacts to take care of deaf patients? Rev Pesqui Cuid Fundam Online. [Internet]. 2013 [cited 2015 Jan 5]; 5(3):283-92. Available from: http://www.seer.unirio.br/index. php/cuidadofundamental/article/view/2065

11. Nóbrega JD, Andrade AB, Pontes RJS, Bosi MLM, Machado MMT. Identidade surda e intervenções em saúde na perspectiva de uma comunidade usuária de língua de sinais. Ciênc Saúde Coletiva. 2012; 17(3):671-9.

12. Bentes IMS, Vidal ECF, Maia ER. Deaf person's perception on health care in a midsize city: an descriptive-exploratory study. Online Braz J Nurs. [Internet] 2011 [cited 2015 Jan 5]; 10(1). Available from: http://www.objnursing.uff.br/index.php/ nursing/article/view/j.1676-4285.2011.3210.2
13. Minayo MCS. O desafio do conhecimento: a pesquisa qualitativa em saúde. São Paulo: Hucitec; 2010.

14. Chaveiro N, Porto CC, Barbosa MA. Relação do paciente surdo com o médico. Rev Bras Otorrinolaringol. 2009; 75(1):147-50.

15. Chaveiro N, Duarte SBR, Freitas AR, Barbosa MA, Porto CC, Fleck MPA. Instrumentos em Língua Brasileira de Sinais para avaliação da qualidade de vida da população surda. Rev Saúde Pública. 2013; 47(3):616-23.

16. Dorziat A, Araújo JR. O intérprete de língua de sinais no contexto da educação inclusiva: o pronunciado e o executado. Rev Bras Educ Espec. 2012; 18(3):391-410.

17. Pivetta EM, Saito DS, Ulbricht VR. Surdos e acessibilidade: análise de um ambiente virtual de ensino e aprendizagem. Rev Bras Educ Espec. 2014; 20(1):147-62.

18. Aragão JS, Magalhães IMO, Coura AS, Silva AFR, Cruz GKP, França ISX. Access and communication of deaf adults: a voice silenced in health services. Rev Pesqui Cuid Fundam Online. [Internet] 2014 [cited 2015 Jan 5]; 6(1):1-7. Available from: http://www.index-f.com/pesquisa/2014pdf/e6001.pdf

19. Brasil. Decreto n. 5.626, 22 de dezembro de 2005. Dispõe sobre a regulamentação da Língua Brasileira de Sinais. Brasília: Presidência da República; 2005.

20. Vianna NG, Cavalcanti MLT, Acioli MD. Princípios de universalidade, integralidade e equidade em um serviço de atenção à saúde auditiva. Ciênc Saúde Coletiva. 2014; 19(7):2179-88. 